\title{
Cloning and Molecular Characterization of groESL Heat-Shock Operon in Methylotrophic Bacterium Methylovorus Sp. Strain SS1 DSM 11726
}

\author{
Chi Yong Eom ${ }^{\dagger}$, Eungbin Kim, Young Tae Ro», Si Wouk Kim ${ }^{\S}$ and Young Min Kim* \\ "Department of Biology, Yonsei University, Seoul 120-749, Korea \\ ${ }^{\ddagger}$ Laboratory of Biochemistry, College of Medicine, Konkuk University, Chungju 380-701, Korea \\ ${ }^{\S}$ Department of Environmental Engineering, Chosun University, Gwangju 501-759, Korea \\ Received 11 July 2005, Accepted 10 September 2005
}

\begin{abstract}
The groESL bicistronic operon of a restricted facultative methylotrophic bacterium Methylovorus sp. strain SS1 DSM 11726 was cloned and characterized. It was found to consist of two ORFs encoding proteins with molecular masses of 11,395 and 57,396 daltons, which showed a high degree of homology to other bacterial GroES and GroEL proteins. The genes were clustered in the transcription order groES-groEL. Northern blot analyses suggested that the groESL operon is transcribed as a bicistronic $2.2-\mathrm{kb}$ mRNA, the steady-state level of which was markedly increased by temperature elevation. Primer extension analysis demonstrated one potential transcription start site preceding the groESL operon, which is located 100bp upstream of the groES start codon. The transcription start site was preceded by a putative promoter region highly homologous to the consensus sequences of Escherichia coli $\sigma^{32}$-type heat shock promoter, which functioned under both normal and heat shock conditions in $E$. coli. Heat shock mRNA was maximally produced by Methylovorus sp. strain SS1 approximately $10 \mathrm{~min}$ after increasing the temperature from 30 to $42^{\circ} \mathrm{C}$. The groESL operon was also induced by hydrogen peroxide or salt shock.
\end{abstract}

Keywords: groESL, Heat-shock operon, Methylosinus sp. SS1, Methylotrophic bacteria

'Present Address: Department of Biochemistry, Stanford University School of Medicine, Stanford, CA 94305, USA

*To whom correspondence should be addressed.

Tel: 82-2-2123-2658; Fax: 82-2-312-5657

E-mail: young547@yonsei.ac.kr

\section{Introduction}

Organisms rapidly synthesize heat shock proteins (Hsps) when exposed to abrupt shifts in temperature (Lindquist and Craig, 1988; Ang et al., 1991; Georgopoulos and Welch, 1993; Becker and Craig, 1994). However, most Hsps are also induced by other environmental stresses, such as, exposure to ethanol, salt, or heavy metals (Segal and Ron, 1998), which suggests that heat shock response is a general stress response. Molecular chaperones and ATP-dependent proteases are prominent among the Hsps (Lindquist and Craig, 1988). Moreover, the primary structures of the Hsp70 (DnaK in Escherichia coli) and Hsp60 (GroEL in E. coli) families, both molecular chaperone families, are highly conserved (Craig et al., 1993; Hendrick and Hartl, 1993; Hartl, 1996).

The chaperonin GroEL (Cpn60) and co-chaperonin GroES (Cpn10) constitute the GroE chaperone, and were originally found to be required for bacteriophage assembly (Tilly et al., 1981). GroE chaperone is involved in the folding and refolding of a number of structurally unrelated proteins (Horwich et al., 1993; Ewalt et al., 1997; Houry, 2001; Hartl and Hayer-Hartl, 2002), is essential for cell viability at all temperatures (Fayet et al., 1989), and is found in bacteria, mitochondria and chloroplasts (Ellis and van der Vies, 1991). In most bacteria studied to date, the genes encoding GroES and GroEL are transcribed as a bicistronic operon in the order groES-groEL (Fayet et al., 1989). Several bacteria are known to have an additional, monocistronic groEL operon, e.g., Synechocystis vulcanus (Furuki et al., 1996), Rhizobium meliloti (Rusanganwa and Gupta, 1993), and Anabaena sp. (Rajaram et al., 2001), whereas several groE operons were found in Rhodobacter sphaeroides (Lee et al., 1997), and Bradyrhizobium japonicum (Babst et al., 1996).

The regulatory mechanism of heat shock response differs among species. In E. coli, the groE operon is regulated by alternative sigma factor $\sigma^{32}$ (Yura et al., 1993). Under heat shock conditions, the groE genes are efficiently transcribed 
from a heat shock promoter located upstream of groES by RNA polymerase cooperating with $\sigma^{32}$ factor (Cowing et al., 1985). Moreover, the groE operon has a second promoter, which can be used under normal growth conditions by RNA polymerase acting with vegetative sigma factor, $\sigma^{70}$ (Zhou et al., 1988). In most Gram-positive bacteria, e.g., in Bacillus subtilis, and in some Gram-negative species, groESL genes are preceded by an inverted repeat (IR) named CIRCE (Controlling Inverted Repeat of Chaperone Expression) (Zuber and Schumann, 1994; Mogk et al., 1997). HrcA repressor binds to CIRCE, and thereby, regulates groE transcription (Hecker et al., 1996; Segal and Ron, 1998).

Methylotrophic bacteria are capable of aerobic growth using carbon compounds containing a single carbon atom $\left(\mathrm{C}_{1}\right)$, like methanol, as the sole energy and carbon source, and therefore could serve as biocatalysts for the conversion of methanol to commercially valuable multicarbon compounds like amino acids and cytochromes (Lidstrom and Stirling, 1990). However, little is known about the nature and regulation of stress responses in methylotrophs, although these bacteria have enormous potential applications environmentally and commercially. The Methylovorus sp. strain SS1 DSM 11726 (Seo and Kim, 1993) belongs to the $\beta$-subdivision proteobacteria and is a Gramnegative, restrinceted facultative methylotrophic bacterium (Bulygina et al., 1990; Bratina et al., 1992). The exposure of Methylovorus sp. strain SS1 to various types of stress, including heat, resulted in the identification of a series of stress proteins (Park et al., 2001). The 60- and 70-kDa stress proteins were shown to be immunologically cross-reactive with GroEL and DnaK of E. coli, respectively (Park et al., 2001). In a previous study, we showed that the dnaK locus of Methylovorus sp. strain $\mathrm{SS} 1$ is composed (in transcription order) of $g r p E-d n a K-d n a J$, and that the transcription start site is preceded by an E. coli $\sigma^{32}$-type heat shock promoter (Eom et al., 2002).
To gain a further understanding of heat shock response in methylotrophic bacteria, we cloned and characterized the groESL operon from Methylovorus sp. strain SS1. Here, we describe the first detailed characterization of the groESL operon in a restricted facultative methylotrophic bacterium.

\section{Materials and Methods}

Bacterial strains, phages, plasmids, and growth conditions The bacterial strains, phages and plasmids used in this study are listed in Table 1. Methylovorus sp. strain SS1 was cultivated at $30^{\circ} \mathrm{C}$ in a standard mineral base medium (Kim and Hegeman, 1981) supplemented with $0.5 \%$ ( vol $/ \mathrm{vol})$ methanol. Heat shock for Methylovorus sp. strain SS1 was performed by transferring cells growing exponentially at $30^{\circ} \mathrm{C}$ to $42^{\circ} \mathrm{C}$. Other stress conditions were provoked by exposing the cells to a final concentration of $5 \%$ (vol $/ \mathrm{vol})$ ethanol, $4 \%$ (wt/ vol) $\mathrm{NaCl}$, or $0.02 \%$ ( vol $/ \mathrm{vol}) \mathrm{H}_{2} \mathrm{O}_{2}$. E. coli strains were grown at $37^{\circ} \mathrm{C}$ on LB agar or in LB broth supplemented with ampicillin $(50 \mu \mathrm{g} / \mathrm{ml})$, if required. For phage infection, $0.2 \%$ (wt/vol) maltose and $10 \mathrm{mM} \mathrm{MgSO}_{4}$ were added to the LB medium. Stocks of recombinant phages were prepared as was described by Sambrook et al. (1989).

DNA manipulations Chromosomal DNA from Methylovorus sp. strain SS1 was isolated from cells at the early stationary growth phase, as described previously (Goldberg and Ohman, 1984). Recombinant DNA techniques, plasmid isolation, and phage lysate preparation were performed using standard protocols (Sambrook et al., 1989). The electrotransformation of $E$. coli was carried out using a Gene Pulser apparatus (Bio-Rad, Hercules). DNA fragments, when necessary, were purified using QIAquick Gel Extraction Kits (Qiagen, Valencia, USA). DNA was sequenced by the dideoxy chain termination method (Sanger et al., 1977) using a Sequenase DNA sequencing kit (version 2.0, US Biochemical Corp., Cleveland)

Table 1. Bacterial strains, phages and plasmids used in this study

\begin{tabular}{|c|c|c|}
\hline Bacterial strain, phage, or plasmid & Genotype or description & Source or reference \\
\hline \multicolumn{3}{|l|}{ Bacterial strains } \\
\hline Methylovorus sp. strain SS1 & Wild type (DSM 11726) & Seo and Kim (1993) \\
\hline \multicolumn{3}{|l|}{ E. coli } \\
\hline $\mathrm{DH} 5 \alpha$ & 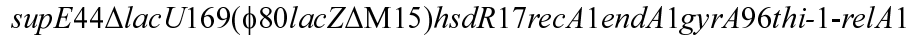 & Stratagene \\
\hline XL1-Blue MRA(P2) & $\begin{array}{l}\Delta(\text { mcrA }) 183, \Delta(\text { mcrCB-hsdSMR-mrr }) 173 \text { endA } 1 \text { supE } 44 \text { thi-1 gyrA } \\
\text { 96rela1lac (P2 lysogen })\end{array}$ & Stratagene \\
\hline \multicolumn{3}{|l|}{ Phages and plasmids } \\
\hline Lambda DASH II & BamHI-digested arms & Stratagene \\
\hline$\lambda \mathrm{E} 601$ & $\lambda$ DASH II derivative harboring $11-\mathrm{kb}$ groE locus & This study \\
\hline$\lambda \mathrm{E} 602$ & $\lambda$ DASH II derivative harboring $16-\mathrm{kb}$ groE locus & This study \\
\hline pGEM-T & 3.0-kb cloning vector; $\mathrm{Am}^{\mathrm{r}}$ & Promega \\
\hline pBluescript II KS+ & 2.9-kb cloning or sequencing vector; $\mathrm{Am}^{\mathrm{r}}$ & Stratagene \\
\hline pGL3-Basic & 4.8-kb promoterless, luciferase reporter vector; $l u c^{+}, \mathrm{Am}^{\mathrm{r}}$. & Promega \\
\hline pSSE1 & pGEM-T harboring 587-bp PCR product & This study \\
\hline pYK100 & pBluescript II KS+ harboring 3.0-kb EcoRI fragment from $\lambda E 601$ & This study \\
\hline pYK101 & pBluescript II KS+ harboring 3.6-kb SalI fragment from $\lambda E 602$ & This study \\
\hline pGL-EP1 & pGL3-Basic harboring groE promoter in right orientation & This study \\
\hline
\end{tabular}


or using a PE 377 automated Sequencer (Perkin-Elmer, Norwalk, USA) at the Korean Basic Science Institute. Sequences were analyzed using BLAST programs on the NCBI (National Center for Biotechnology Information) network server.

Amplification of groEL DNA by PCR The DNA sequence corresponding to partial GroEL was amplified by PCR from Methylovorus sp. strain SS1 genomic DNA using two degenerate primers. The forward primer EF (5' GGYACNACNACNGCNACN GCN 3') and the reverse primer ER (5' RTCRCCRAARCCNGGN GCYTT 3') were synthesized to match the highly conserved region of bacterial GroEL homologues (corresponding to aa 88-94, GTTTATV, and aa 277-283, KAPGFGD, respectively, of E. coli GroEL). PCR was conducted using a Fast Air Temp-Cycler FTC2000 (Daehan Medical Co., Seoul) using the 30 cycles of; $95^{\circ} \mathrm{C}$ for $20 \mathrm{~s}, 66^{\circ} \mathrm{C}$ for $15 \mathrm{~s}, 72^{\circ} \mathrm{C}$ for $15 \mathrm{~s}$. The PCR product was eluted from agarose gel, labeled with digoxigenin-11-dUTP (DIG), and used as a probe for Southern blot and plaque hybridization.

Southern blot analysis Genomic DNA of Methylovorus sp. strain SS1 was digested with EcoRI, EcoRV, NcoI, PstI, or SalI (Promega, Madison, USA), separated by agarose gel electrophoresis, and transferred to Hybond-N+ membranes (Amersham, Arlington Heights, USA) by capillary blotting. Hybridization was carried out at $68^{\circ} \mathrm{C}$ for $16 \mathrm{~h}$ in $5 \mathrm{X} \mathrm{SSC}, 0.02 \%$ sodium dodecyl sulfate (SDS), $0.1 \% \mathrm{~N}-$ lauroylsarcosine, and $1 \%$ blocking reagent using a DIG-labeled probe. Colorimetric detection of positive bands was performed as described by the manufacturer (Boehringer Mannheim, Mannheim, Germany).

Genomic library construction and screening A Methylovorus sp. strain SS1 genomic library was constructed in $\lambda$ DASH II vector (Stratagene, La Jolla, USA). Briefly, Methylovorus sp. strain SS1 DNA was partially digested with Sau3AI, ligated to $\lambda$ DASH II, packaged with Stratagene Gigapack II Gold packaging extracts, and transduced into E. coli XL1-Blue MRA (P2) cells. Plaque replicas were screened with the DIG-labeled probes.

RNA isolation and Northern blot and Slot blot analyses Total RNA was isolated from Methylovorus sp. strain SS1, as described previously (Eom et al., 2002). DNA contamination was removed by DNase I treatment. For each sample, $10 \mu \mathrm{g}$ of total RNA was electrophoresed on denaturing $1.2 \%$ agarose/formaldehyde gels and transferred to Hybond-N+ membranes over $2 \mathrm{~h}$ in a $1 \mathrm{M}$ ammonium acetate solution by using a vacuum blotter (Hoefer Scientific Instruments, San Francisco). Northern blots were subjected to hybridization with ${ }^{32} \mathrm{P}$-labeled DNA fragments internal to Methylovorus sp. strain SS1 groES and groEL, respectively. The conditions used for hybridization and washing have been described elsewhere (Eom et al., 2002). For Slot blotting, we used a slot blotter (PR648, Hoefer Scientific Instruments) according to the manufacturer's instructions.

Primer extension mapping Primer extension mapping was used to determine the transcription start site of the Methylovorus sp. strain SS1 groESL operon using total RNA, an avian myoblastosis virus reverse transcriptase primer extension system (Promega), and a 21-mer oligonucleotide primer (5'CGCTTCAATTCGCTTGACC
AC3'), complementary to nucleotide positions 31 to 51 downstream of the groES start codon. The oligonucleotide was end-labeled with $\left[\gamma-{ }_{-}^{32} \mathrm{P}\right]$ ATP, using a standard technique (Sambrook et al., 1989), and hybridized to $10 \mu \mathrm{g}$ of total RNA isolated from Methylovorus sp. strain SS1 cells before and after heat shock treatment for $5 \mathrm{~min}$. The annealed primer was extended at $42^{\circ} \mathrm{C}$ for $30 \mathrm{~min}$ using $10 \mathrm{U}$ of reverse transcriptase. Loading dye ( $98 \%$ formamide, $10 \mathrm{mM}$ EDTA, $0.1 \%$ xylene cyanol, $0.1 \%$ bromophenol blue) was added to the reaction and the mixture was loaded onto a $6 \%$ polyacrylamideurea sequencing gel with the corresponding sequencing reaction of the upstream flanking region of the groES gene.

Western blot analysis To obtain cell-free extracts of Methylovorus sp. strain SS1, bacterial cells were harvested, washed twice with $50 \mathrm{mM}$ Tris- $\mathrm{HCl}$ (pH 7.5), and resuspended in the same buffer with $250 \mathrm{mM} \mathrm{NaCl}$. After repeated sonification, protein concentrations were determined using the Bradford method (Bradford, 1976) with bovine serum albumin as a standard. For Western blot analysis we used $50 \mu \mathrm{g}$ of cell lysate. SDS-PAGE was carried out using $12 \%$ polyacrylamide gels, from which proteins were transferred to nitrocellulose membranes (Schleicher and Schuell) using a Towbin buffer system (Towbin et al., 1979). Proteins were probed with rabbit polyclonal anti-GroEL antibody (Sigma, St. Louis, USA), and bound antibodies were detected by peroxidase-conjugated enhanced chemiluminescence (Amersham).

Promoter assay The activity of Methylovorus sp. strain SS1 groES promoter was assayed in $E$. coli $\mathrm{DH} 5 \alpha$ transformed with a plasmid (pGL-EP1) carrying Methylovorus sp. strain SS1 groE promoter. The forward primer EPF (5'CGCGGATCCATGCCCTCTTG3'), corresponding to nucleotide positions 33 to 43 upstream of the transcription start site with artificial BamHI site (underlined and extra nucleotides CGC, and the reverse primer EPR (5'GACGAAT TCTCATTTCAAATC3'), which is complementary to the nucleotide positions 34 to 54 downstream of the transcriptions start site except that the nucleotide $\mathrm{G}$ complementary to the position 47 downstream of the transcription start site was replaced by nucleotide $\mathrm{T}$ to make artificial EcoRI site (underlined), were used to amplify the Methylovorus sp. strain SS1 promoter region. The amplied 156-bp fragments were ligated to pBluescript II KS+ to make pBE-3. The pBE-3 was then digested with $\mathrm{SacI}$ and $\mathrm{XhoI}$ and the resulting fragment containing the PCR fragment was ligated to pGL3-Basic digested with the same enzymes to make pGL3-EP1. Luciferase activity was assayed using luciferase assay reagent (Promega) and a luminometer (T2020, Turner Designs, Sunnyvale, USA) according to the manufacturer's instructions.

Nucleotide sequence accession number The nucleotide sequences of Methylovorus sp. strain SS1 groESL operon was assigned the GenBank accession no. AF152236.

\section{Results and Discussion}

Molecular cloning of the groESL operon By using the degenerate oligonucleotide primers EF and ER, which were synthesized using the sequence of a highly conserved region of bacterial GroEL-like proteins, a 587-bp DNA fragment was 


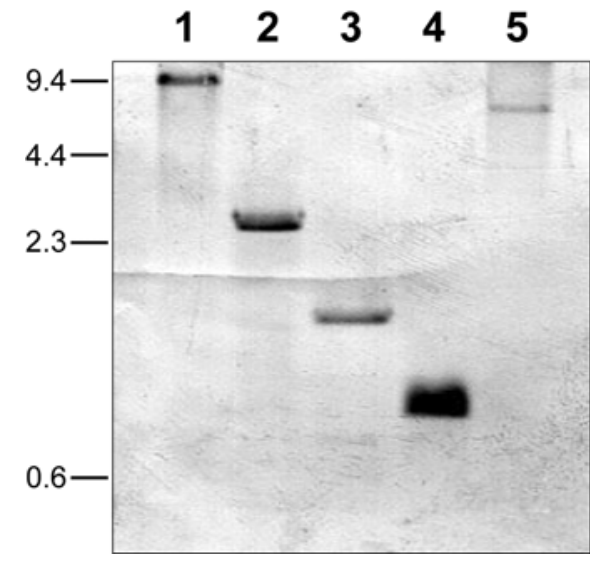

Fig. 1. Southern blot analysis of Methylovorus sp. strain SS1 genomic DNA digested with various restriction enzymes. Lanes: 1, EcoRI; 2, EcoRV; 3, NcoI; 4, PstI 5, SalI. A DIG-labeled 587-bp fragment of the Methylovorus sp. strain SS1 groEL gene was used as a probe. Bars indicate molecular sizes.

amplified by PCR using Methylovorus sp. strain SS1 genomic DNA as a template (data not shown), cloned into pGEM-T vector (Promega) to construct pSSE1, sequenced, and found to be $72 \%$ identical to the sequence that encodes amino acid positions 88 through 283 of E. coli GroEL. Southern blot analysis showed that the DIG-labeled Methylovorus sp. strain SS1 groEL probe hybridizes to only one fragment formed by the restriction enzyme reactions, which indicates that Methylovorus sp. strain SS1 contains a single copy of the groEL gene (Fig. 1).

Forty-five positive clones were obtained by plaque hybridization of the lambda library of Methylovorus sp. strain SS1 using random-primed probes. Of the positive clones, $\lambda \mathrm{E} 601$, which contained an 11-kb insert DNA, was digested with EcoRI and subjected to agarose gel electrophoresis for Southern blotting. A 3-kb positive DNA fragment was isolated from the gel and ligated into an EcoRI-digested pBluescript II KS+ plasmid (Stratagene). The resulting plasmid is referred to as pYK100 (Fig. 2). A database homology search based on nucleotide sequence analysis of cloned fragment DNA showed that the entire groES gene and a portion of the groEL gene were present in pYK100. A 3.6-kb SalI DNA fragment from the other clone ( $\lambda \mathrm{E} 602)$, which contained a $16-\mathrm{kb}$ insert DNA, was also cloned into pBluescript and named pYK101 (Fig. 2). pYK101 was found to contain full length genes encoding Methylovorus sp. strain SS1 GroEL.

Characterzation of Methylovorus sp. strain SS1 bicistronic groESL operon Sequence analysis of the relevant regions of pYK100 and pYK101 revealed the presence of two contiguous ORFs (Fig. 2). The first ORF (ORF1) was 318-bp long and encodes a polypeptide of 105 aa with a predicted molecular mass of 11,395 daltons, and has a calculated $\mathrm{pI}$ of 5.8. This polypeptide (called Methylovorus sp. strain SS1 GroES) exhibited considerable homology to the GroES-like proteins of other bacterial species. In particular, it showed overall identity to GroES homologues of $\alpha$-subdivision Proteobacteria Agrobacterium tumefaciens (Segal and Ron, 1993), $\beta$-subdivision Proteobacteria Nitrosomonas europaea (Chain et al., 2003), and Neisseria meningitidis (Tettelin et al., 2000), and of $\gamma$ subdivision Proteobacteria E. coli (Tilly and Georgopoulos, 1982 ) of $54.0 \%, 68.0 \%, 66.0 \%$, and $49.5 \%$, respectively.

The start codon of the second ORF (ORF2) was found to be located 46-bp downstream of the stop codon (TGA) of ORF1. ORF2 is 1,623-bp long and encodes a polypeptide of 540 aa with a predicted molecular mass of 57,396 dalton and has a predicted $\mathrm{pI}$ of 5.1. The deduced amino acid residues were aligned with the complete sequences of the GroEL homologues of A. tumefaciens (66.7\% identity), $N$. europaea (74.0\% identity), $N$. meningitidis (71.0\% identity), and E. coli (70.1\% identity). However, We could not find out tandem repeats of the Gly-Gly-Met that is found in C-terminus of many bacterial GroEL proteins (McLennan et al., 1993). This analysis indicates that GroEL is more conserved among the species than GroES, and that the GroES and GroEL of Methylovorus sp. strain SS1, which belongs to $\beta$-subdivision of Proteobacteria, are more closely related to the proteins found in bacteria that belong to the same phylogenetic group.

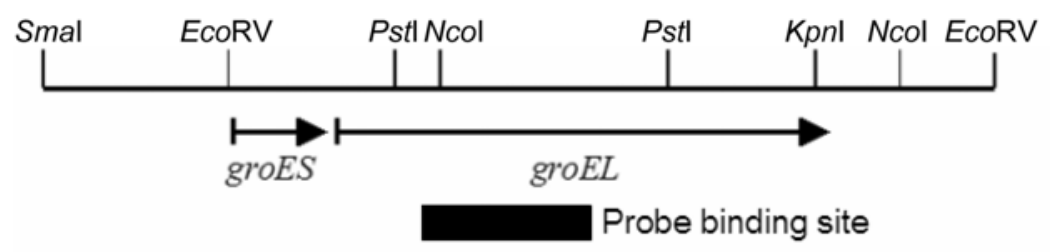

$3.0 \mathrm{~kb}$ EcoRI fragment

$3.6 \mathrm{~kb}$ Sall fragment $500 \mathrm{bp}$

Fig. 2. Restriction maps of the Methylovorus sp. strain SS1 groESL operon. A 3.0-kb EcoRI fragment in pYK100 and a 3.6-kb Sall fragment in pYK101 are indicated below the map. The positions and lengths of ORFs and direction (arrows) were determined by nucleotide sequencing. The probe-binding site is marked under the map. 


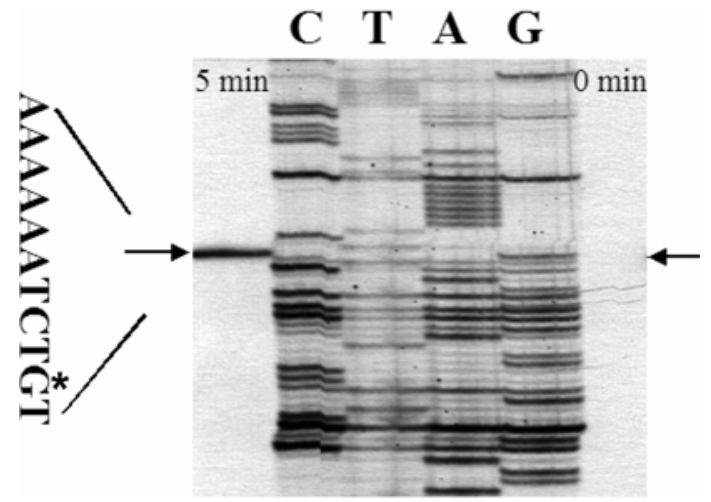

Fig. 3. Mapping of the groESL transcription start site. Primer extension products were generated by reverse transcription of total RNA from Methylovorus sp. strain SS1 cells heat-shocked for 5 min. Lanes $\mathrm{G}, \mathrm{A}, \mathrm{T}$ and $\mathrm{C}$ show the dideoxy-sequencing ladder obtained using the primer used for primer extension. An asterisk shows the transcriptional start site.

This further suggests that GroES identity could be useful as an index for studying phylogenetic relationships in Proteobacteria.

Features of the noncoding regions Both ORF1 and ORF2 are preceded by putative ribosome-binding sites (AAGGAGA) (Shine and Dalgarno, 1974), 8 and $10 \mathrm{bp}$ upstream of the AUG start codon, respectively. Primer extension analysis identified a presumed transcription start site corresponding to a $\mathrm{G}$ residue located $100 \mathrm{bp}$ upstream of the translation start codon of the groES gene (Fig. 3). An analysis of the upstream region of the transcriptional start site revealed the presence of consensus sequences of the -35 (5' CCCTCTTGAA 3') and the -10 (5' ACCCATATC $3^{\prime}$ ) regions found in $\sigma^{32}$-type promoters of $\alpha-, \beta$-, and $\gamma$-subdivision Proteobacteria, such as, in $C$. crescentus (Roberts et al., 1996), N. europaea (Iizumi and Nakamura, 1997), and E. coli (Cowing et al., 1985), respectively. Furthermore, a sequence of dyad symmetry between positions -70 and -35 was identified (5' AAGAGGGCATTGAA-7 bpTTCAATGCCCTCTT 3'). Stem-loop structures (designated CIRCE elements that control inverted repeat of chaperone expression) have been described in the $5^{\prime}$ noncoding regions of many bacterial groE and dnaK genes (Zuber and Schumann, 1994; Avedissian and Lopes Gomes, 1996; Hecker et al., 1996; Segal and Ron, 1996). However, the Methylovorus sp. strain SS1 sequence differs from the CIRCE consensus sequence (5' TTAGCACTC-N9-GAGTGCTAA 3'). This indicates that a different mechanism is involved in the translational regulation of the groESL operon in Methylovorus sp. strain $\mathrm{SS} 1$. Analysis of the downstream region of the groEL gene revealed an inverted repeat capable of forming a stem-loop structure with a calculated free energy of $-103.8 \mathrm{~kJ}$ per mol. The repeat was followed by a short run of Ts, suggesting that it may act as a rho-independent transcriptional terminator.

To determine whether the putative $\sigma^{32}$-type promoter of the groESL operon of Methylovorus sp. strain SS1 is functional in $E$. coli, competent $E$. coli cells were transformed with plasmid

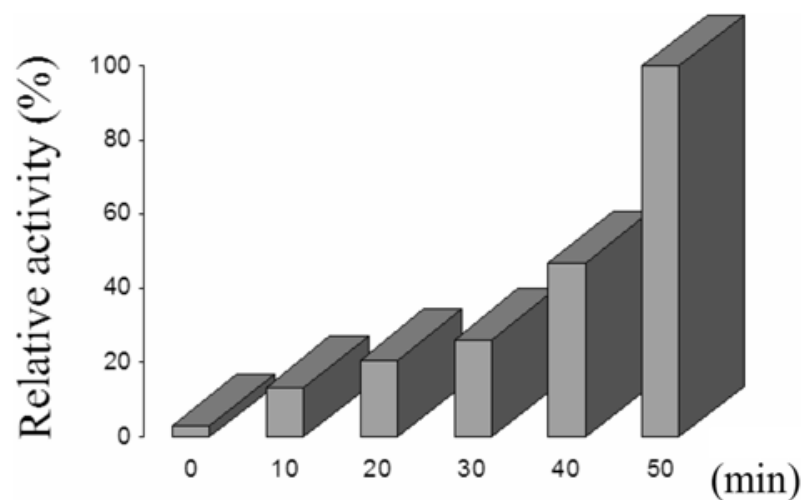

Fig. 4. Activity of Methylovorus sp. strain SS1 groESL promoter in E. coli. E. coli cells transformed with pGL-EP1 containing a DNA fragment including the Methylovorus sp. strain SS1 groESL promoter region were subjected to a temperature shift from $28^{\circ} \mathrm{C}$ to $37^{\circ} \mathrm{C}$ over $10-50 \mathrm{~min}$; luciferase activity was measured as described in Materials and Methods. Activity (240.9 relative light units) measured at $50 \mathrm{~min}$ after the temperature shift was set as $100 \%$. The activities presented are the mean of three tests.

(called pGL-EP1) containing Methylovorus sp. strain SS1 groE promoter. Cells were subjected to a temperature shift from $28^{\circ} \mathrm{C}$ to $37^{\circ} \mathrm{C}$ for $10-50 \mathrm{~min}$, and luciferase activity was measured (Fig. 4). The E. coli cells transformed with pGLEP1 and induced at $37^{\circ} \mathrm{C}$ for $10,20,30,40$ and $50 \mathrm{~min}$ exhibited luciferase activities 4.3-, 6.6-, 8.5-, 15.0-, and 32.4fold higher than those of cells harboring pGL3-Basic vector stored at $28^{\circ} \mathrm{C}$ for the corresponding period, respectively. This observation indicates that Methylovorus sp. strain SS1 groESL promoter is capable of functioning as a heat shock promoter in E. coli.

Transcription of the groESL bicistronic operon In Methylovorus sp. strain SS1, groES and groEL are separated by a 46-bp intergenic region, which contains no specific promoter sequences, but does contain ribosome binding sites. This suggests that these two genes may be co-transcribed as a single transcript. The in vivo transcripts of the groESL bicistronic operon were detected by Northern blot analysis. Total RNA was isolated from Methylovorus sp. strain SS1 cells grown exponentially at $30^{\circ} \mathrm{C}$, subcultured, and subsequently heat-shocked for 5-60 min at $42^{\circ} \mathrm{C}$. A ${ }^{32} \mathrm{P}$-labeled 587 -bp-containing groES probe hybridized to a single 2.2-kb transcript (Fig. 5). RNA transcripts of the same size were also detected in an experiment using groELspecific probe (data not shown). This indicates in that Methylovorus sp. strain SS1 groES and groEL consist of a bicistronic operon that is transcribed in the order groESgroEL. groESL mRNA was expressed at a very low level in Methylovorus sp. strain SS1 grown at $30^{\circ} \mathrm{C}$ (Fig. 5. lane 1), which concurs with the result of primer extension analysis (Fig. 3). After shifting Methylovorus sp. strain SS1 cells to $42^{\circ} \mathrm{C}$, a rapid increase in the groESL mRNA level was observed, which reached a maximum after $10 \mathrm{~min}$ and then 
$\begin{array}{llllllllll}0 & 5 & 10 & 15 & 20 & 30 & 40 & 50 & 60 & (\mathrm{~min})\end{array}$
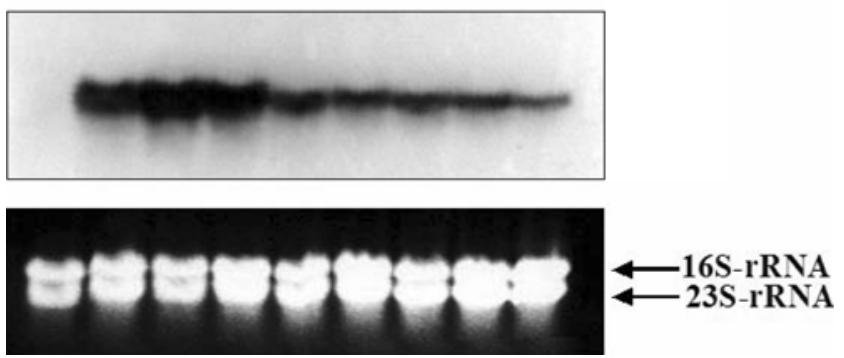

Fig. 5. Northern blot analysis of groESL locus genes. Northern blot analysis was performed using a ${ }^{32} \mathrm{P}$-labeled groES probe and total RNAs prepared from cells harvested at the indicated times after transferring cells growing exponentially at $30^{\circ} \mathrm{C}(0 \mathrm{~min})$ to $42^{\circ} \mathrm{C}$, as described in Materials and Methods. Each lane contains $10 \mu \mathrm{g}$ of RNA. The same result was obtained using a groELspecific probe.

decreased from $15 \mathrm{~min}$ (Fig. 5). This result shows that Methylovorus sp. strain SS1 groESL is a typical heat shock operon, and that its expression level is controlled at the transcription level. To confirm Northern blot results, Western blot analysis was conducted, and the results showed that Methylovorus sp. strain SS1 produces similar levels of GroEL for $1 \mathrm{~h}$ after a temperature shift (Fig. 6), which suggests that the level of Methylovorus sp. strain SS1 GroEL may be controlled at the translational and transcriptional levels.

groESL operon is a general stress response operon Slot blot hybridization revealed that Methylovorus sp. strain SS1 groESL was inducible by oxidative (Fig. 7, lane 4) and salt stresses (Fig. 7, lane 5) in addition to temperature shifts (Fig. 7, lane 1). This implies that the proteins encoded by Methylovorus sp. strain SS1 groESL operon may function as general shock proteins. Rifampicin $(100 \mu \mathrm{g} / \mathrm{ml})$, when added to culture $2 \mathrm{~min}$ before heat-shock treatment, was found to strongly prevent an increase in the groESL mRNA level after a temperature shift (Fig. 7, lane 2). This confirms that the observed increase in the amount Methylovorus sp. strain SS1 groESL operon mRNA was a result of enhanced RNA synthesis under stressed conditions.

$\begin{array}{llllllllll}0 & 5 & 10 & 15 & 20 & 30 & 40 & 50 & 60 & (\mathrm{~min})\end{array}$

Fig. 6. Immunoblotting of GroEL in Methylovorus sp. strain $\mathrm{SS} 1$. The expression of groEL in cells grown on methanol was analyzed using ECL Western blot protocols after subjecting extracts prepared from cells grown on $0.5 \%$ methanol $(\mathrm{vol} / \mathrm{vol})$ at $30^{\circ} \mathrm{C}$ followed by incubation at $42^{\circ} \mathrm{C}$ for $0,5,10,15,20,30,40,50$, or $60 \mathrm{~min}$ to denaturing PAGE (10\% acrylamide, $0.1 \%$ SDS), as described in Materials and Methods. Extracts from cells incubated at $30^{\circ} \mathrm{C}$ for $5,10,15,20,30,40,50$, or $60 \mathrm{~min}$ exhibited the same expression pattern as that of 0 min stage cells.

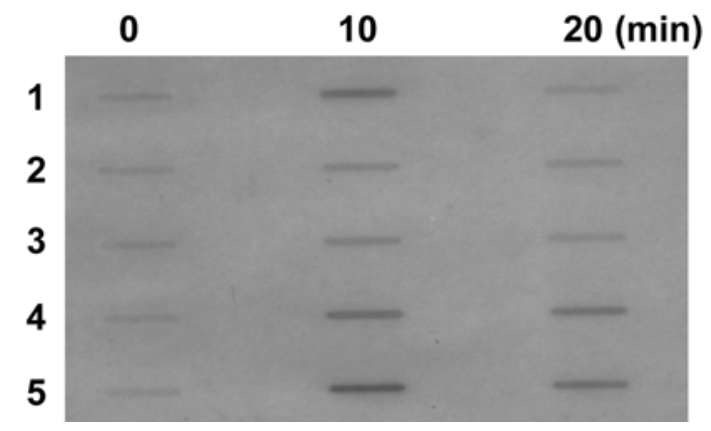

Fig. 7. Transcription of the groESL operon under different stresses. Slot blot analysis with total RNAs prepared from cells grown at $30^{\circ} \mathrm{C}$ followed by incubation at $42^{\circ} \mathrm{C}$ (lane 1), and cells treated with rifampicin for $2 \mathrm{~min}$ at $30^{\circ} \mathrm{C}$ followed by incubation at $42^{\circ} \mathrm{C}$ (lane 2), or treated with ethanol (lane 3), $\mathrm{H}_{2} \mathrm{O}_{2}$ (lane 4), or $\mathrm{NaCl}$ (lane 5) were performed using ${ }^{32} \mathrm{P}$-labeled 587-bp groEL probes. 10 and $20 \mathrm{~min}$ indicate the times when cells were harvested after being exposed to stress conditions. Five $\mu \mathrm{g}$ of total RNA was applied per slot.

Acknowledgment This work was supported by a research grant from Yonsei University (Grant No. 2002-1-0162) to YMK.

\section{References}

Ang, D., Liberek, K., Skowyra, D., Zylicz, M. and Georgopoulos, C. (1991) Biological role and regulation of the universally conserved heat shock proteins. J. Biol. Chem. 266, 2423324236.

Avedissian, M., and Lopes Gomes, S. (1996) Expression of the groESL operon is cell-cycle controlled in Caulobacter crescentus. Mol. Microbiol. 19, 79-89.

Babst, M., Hennecke, H. and Fischer, H. M. (1996) Two different mechanisms are involved in the heat-shock regulation of chaperonin gene expression in Bradyrhizobium japonicum. Mol. Microbiol. 19, 827-839.

Becker, J. and Craig, E. A. (1994) Heat-shock proteins as molecular chaperones. Eur. J. Biochem. 219, 11-23.

Bradford, M. M. (1976) A rapid and sensitive method for the quantitation of microgram quantities of protein utilizing the principle of protein-dye binding. Anal. Biochem. 72, 248-254.

Bratina, B. J., Brusseau, G. A. and Hanson, R. S. (1992) Use of $16 \mathrm{~S}$ rRNA analysis to investigate phylogeny of methylotrophic bacteria. Intl. J. Syst. Bacteriol. 42, 645-648.

Bulygina, E. S., Galchenko, V. F., Govorukhina, N. I., Netrusov, A. I., Nikitin, D. I., Trotsenko, Y. A. and Chumakov, K. M. (1990) Taxomic studies on methylotrophic bacteria by $5 \mathrm{~S}$ ribosomal RNA sequencing. J. Gen. Microbiol. 136, 441-446.

Chain, P., Lamerdin, J., Larimer, F., Regala, W., Lao, V., Land, M., Hauser, L., Hooper, A., Klotz, M., Norton, J., SayavedraSoto, L., Arciero, D., Hommes, N., Whittaker, M. and Arp, D. (2003) Complete genome sequence of the ammonia-oxidizing bacterium and obligate chemolithoautotroph Nitrosomonas europaea. J. Bacteriol. 185, 2759-2773.

Cowing, D. W., Bardwell, J. C., Craig, E. A., Woolford, C., Hendrix, R. W. and Gross, C. A. (1985) Consensus sequence 
for Escherichia coli heat shock gene promoters. Proc. Natl. Acad. Sci. USA 82, 2679-2683.

Craig, E. A., Gambill, B. D. and Nelson, R. J. (1993) Heat shock proteins: molecular chaperones of protein biogenesis. Microbiol. Rev. 57, 402-414.

Ellis, R. J. and van der Vies, S. M. (1991) Molecular chaperones. Annu. Rev. Biochem. 60, 321-347.

Eom, C. Y., Park, S. T., Kim, E., Ro, Y. T., Kim, S. W. and Kim, Y. M. (2002) Cloning, molecular characterization, and transcriptional analysis of dnaK operon in a methylotrophic bacterium Methylovorus sp. strain SS1 DSM 11726. Mol. Cells 14, 245-254.

Ewalt, K. L., Hendrick, J. P., Houry, W. A. and Hartl, F. U. (1997) In vivo observation of polypeptide flux through the bacterial chaperonin system. Cell 90, 491-500.

Fayet, O., Ziegelhoffer, T. and Georgopoulos, C. (1989) The groES and groEL heat shock gene products of Escherichia coli are essential for bacterial growth at all temperatures. $J$. Bacteriol. 171, 1379-1385.

Furuki, M., Tanaka, N., Hiyama, T. and Nakamoto, H. (1996) Cloning, characterization and functional analysis of groEL-like gene from thermophilic cyanobacterium Synechococcus vulcanus, which does not form an operon with groES. Biochim. Biophys. Acta 1294, 106-110.

Georgopoulos, C. and Welch, W. J. (1993) Role of the major heat shock proteins as molecular chaperones. Annu. Rev. Cell. Biol. 9, 601-634.

Goldberg, J. B. and Ohman, D. E. (1984) Cloning and expression in Pseudomonas aeruginosa of a gene involved in the production of alginate. J. Bacteriol. 158, 1115-1121.

Hartl, F. U. (1996) Molecular chaperones in cellular protein folding. Nature 381, 571-579.

Hartl, F. U. and Hayer-Hartl, M. (2002) Molecular chaperones in the cytosol: from nascent chain to folded protein. Science $\mathbf{2 9 5}$, 1852-1858.

Hecker, M., Schumann, W. and Volker, U. (1996) Heat-shock and general stress response in Bacillus subtilis. Mol. Microbiol. 19, 417-428.

Hendrick, J. P. and Hartl, F. U. (1993) Molecular chaperone functions of heat-shock proteins. Annu. Rev. Biochem. 62, 349384.

Horwich, A. L., Low, K. B., Fenton, W. A., Hirshfield, I. N. and Furtak, K. (1993) Folding in vivo of bacterial cytoplasmic proteins: role of GroEL. Cell 74, 909-917.

Houry, W. A. (2001) Chaperone-assisted protein folding in the cell cytoplasm. Curr. Protein Pept. Sci. 2, 227-244.

Iizumi, T. and Nakamura, K. (1997) Cloning, nucleotide sequence, and regulatory analysis of the Nitrosomonas europaea dnaK gene. Appl. Environ.Microbiol. 63, 1777-1784.

Kim, Y. M. and Hegeman, G. D. (1981) Purification and some properties of carbon monoxide dehydrogenase from Pseudomonas carboxydohydrogena. J. Bacteriol. 148, 904-911.

Lee, W. T. Terlesky, K. C. and Tabita, F. R. (1997) Cloning and characterization of two groESL operons of Rhodobacter sphaeroides: transcriptional regulation of the heat-induced groESL operon. J. Bacteriol. 179, 487-495.

Lidstrom, M. E. and Stirling, D. I. (1990) Methylotrophs: genetics and commercial applications. Annu. Rev. Microbiol. 44, 27-58.

Lindquist, S. and Craig, E. A. (1988) The heat-shock proteins. Annu. Rev. Genet. 22, 631-677.
McLennan, N. F., Girshovich, A. S., Lissin, N. M., Charters, Y. and Masters, M. (1993) The strongly conserved carboxylterminus glycine-methionine motif of the Escherichia coli GroEL chaperonin is dispensable. Mol. Microbiol. 7, 49-58.

Mogk, A., Homuth, G., Scholz, C., Kim, L., Schmid, F. X. and Schumann, W. (1997) The GroE chaperonin machine is a major modulator of the CIRCE heat shock regulon of Bacillus subtilis. EMBO J. 16, 4579-4590.

Park, J. H., Kim, S. W., Kim, E., Ro, Y. T. and Kim, Y. M. (2001) Stress-shock response of a methylotrophic bacterium Methylovorus sp. strain SS1 DSM 11726. J. Microbiol. 37, 162-167.

Rajaram, H., Ballal, A. D., Apte, S. K., Wiegert, T. and Schumann, W. (2001) Cloning and characterization of the major groESL operon from a nitrogen-fixing cyanobacterium Anabaena sp. strain L-31. Biochim. Biophys. Acta 1519, 143146.

Roberts, R. C., Toochinda, C., Avedissian, M., Baldini, R. L., Gomes, S. L. and Shapiro, L. (1996) Identification of a Caulobacter crescentus operon encoding hrcA, involved in negatively regulating heat-inducible transcription, and the chaperone gene grpE. J. Bacteriol. 178, 1829-1841.

Rusanganwa, E. and Gupta, R. S. (1993) Cloning and characterization of multiple groEL chaperonin-encoding genes in Rhizobium meliloti. Gene 126, 67-75.

Sambrook, J., Fritsch, E. F. and Maniatis, T. (1989) Molecular Cloning: A Laboratory Manual, Cold Spring Harbor Laboratory Press, New York, USA.

Sanger, F., Nicklen, S., and Coulson, A.R. (1977) DNA sequencing with chain-terminating inhibitors. Proc. Natl. Acad. Sci. USA 74, 5463-5467.

Segal, G. and Ron, E. Z. (1993) Heat shock transcription of the groESL operon of Agrobacterium tumefaciens may involve a hairpin-loop structure. J. Bacteriol. 175, 3083-3088.

Segal, G. and Ron, E. Z. (1996) Heat shock activation of the groESL operon of Agrobacterium tumefaciens and the regulatory roles of the inverted repeat. J. Bacteriol. 178, 36343640.

Segal, G. and Ron, E. Z. (1998) Regulation of heat-shock response in bacteria. Ann. New York Acad. Sci. 851, 147-151.

Seo, S. A. and Kim, Y. M. (1993) Isolation and characterization of a restricted facultatively methylotrophic bacterium Methylovorus sp. strain SS1. Kor. J. Microbiol. 31, 179-183.

Shine, J. and Dalgarno, L. (1974) The 3'-terminal sequence of Escherichia coli $16 \mathrm{~S}$ ribosomal RNA: complementarity to nonsense triplets and ribosome binding sites. Proc. Natl. Acad. Sci. USA 71, 1342-1346.

Tettelin, H., Saunders, N. J., Heidelberg, J., Jeffries, A. C., Nelson, K. E., Eisen, J. A., Ketchum, K. A., Hood, D. W., Peden, J. F., Dodson, R. J., Nelson, W. C., Gwinn, M. L., DeBoy, R., Peterson, J. D., Hickey, E. K., Haft, D. H., Salzberg, S. L., White, O., Fleischmann, R. D., Dougherty, B. A., Mason, T., Ciecko, A., Parksey, D. S., Blair, E., Cittone, H., Clark, E. B., Cotton, M. D., Utterback, T. R., Khouri, H., Qin, H., Vamathevan, J., Gill, J., Scarlato, V., Masignani, V., Pizza, M., Grandi, G., Sun, L., Smith, H. D., Fraser, C. M., Moxon, E. R., Rappuoli, R. and Venter, J. C. (2000) Complete genome sequence of Neisseria meningitidis serogroup B strain MC58. Science 287, 1809-1815.

Tilly, K. and Georgopoulos, C. (1982) Evidence that the two 
Escherichia coli groE morphogenetic gene products interact in vivo. J. Bacteriol. 149, 1082-1088.

Tilly, K., Murialdo, H. and Georgopoulos, C. (1981) Identification of a second Escherichia coli groE gene whose product is necessary for bacteriophage morphogenesis. Proc. Natl. Acad. Sci. USA 78, 1629-1633.

Towbin, H., Staehelin, T. and Gordon, J. (1979) Electrophoretic transfer of proteins from polyacrylamide gels to nitrocellulose sheets: procedure and some applications. Proc. Natl. Acad. Sci. USA 76, 4350-4354.
Yura, T., Nagai, H. and Mori, H. (1993) Regulation of the heatshock response in bacteria. Annu. Rev. Microbiol. 47, 321-350.

Zhou, Y. N., Kusukawa, N., Erickson, J. W., Gross, C. A. and Yura, T. (1988) Isolation and characterization of Escherichia coli mutants that lack the heat shock sigma factor sigma 32. $J$. Bacteriol. 170, 3640-3649.

Zuber, U. and Schumann, W. (1994) CIRCE, a novel heat shock element involved in regulation of heat shock operon dnaK of Bacillus subtilis. J. Bacteriol. 176, 1359-1363. 